\title{
INCIDENTAL CARCINOMA IN LAPAROSCOPIC CHOLECYSTECTOMY
}

\author{
V. Satish¹, Sudhir. M², Sridhar. S³ Sunil Kumar Shetty. S4. \\ 1. Professor and HOD, Department of General Surgery, KIMS Hospital and Research Center. \\ 2. Associate Professor, Department of General Surgery, KIMS Hospital and Research Center. \\ 3. Assistant Professor, Department of General Surgery, KIMS Hospital and Research Center. \\ 4. Senior Resident, Department of General Surgery, KIMS Hospital and Research Center.
}

\section{CORRESPONDING AUTHOR:}

Dr. Sunil Kumar Shetty. S,

K.R. Road, V.V.Puram,

Bangalore 560004

E-mail: sunilkumarshettys@gmail.com

\section{HOW TO CITE THIS ARTICLE:}

V. Satish, Sudhir. M, Sridhar. S, Sunil Kumar Shetty. S. "Incidental Carcinoma in Laparoscopic Cholecystectomy". Journal of Evolution of Medical and Dental Sciences 2013; Vol2, Issue 26, July 1; Page: $4792-4797$.

ABSTRACT: Background: The clinical manifestations of gall bladder carcinoma are generally indistinguishable from those associated with cholecystitis or cholelithiasis. Most of the cases of GB carcinoma are diagnosed during or after surgery performed for stones or benign biliary diseases. Advanced stage of the disease is because of delayed diagnosis and this leads to its poor prognosis.

AIMS: To study the frequency of incidental carcinoma of gall bladder in patients undergoing routine cholecystectomy. CONCLUSIONS: The rate of incidental carcinoma of gall bladder in our setting was found to be $2.15 \%$. Our study strongly recommends routine histopathological examination in all cholecystectomy specimens as they help in detection of majority of cases of occult carcinoma GB.

KEY WORDS: Incidental Carcinoma, Laparoscopic cholecystectomy

INTRODUCTION: Cholecystectomy is the most common major abdominal procedure performed worldwide. Its annual incidence is estimated around 1 million amongst which 500-600 thousand cases in the US ${ }^{1}$. Carcinoma of gallbladder is the most common malignancy of the biliary tract and the fifth most common cancer of digestive tract 2,3 . The clinical manifestations of gall bladder carcinoma are generally indistinguishable from those associated with cholecystitis or cholelithiasis. Around $90 \%$ of GB (Gall bladder) carcinoma has accompanying stones ${ }^{4}$. However, only $0.5-3 \%$ of patients with cholelithiasis will develop gallbladder cancer. ${ }^{5}$ Most of the cases of GB carcinoma are diagnosed during or after surgery performed for stones or benign biliary diseases. ${ }^{6}$ Preoperative diagnosis of GB carcinoma occurs in less than $20.0 \%$ of patients. ${ }^{7}$ Advanced stage of the disease is because of delayed diagnosis and this leads to its poor prognosis except when diagnosed at early stages incidentally during routine cholecystectomies. Thus some of the surgeons recommend surgery even for the patient with asymptomatic gall bladder stones because of its likelihood to harbour occult malignancy. ${ }^{8}$ Role of histopathology of gall bladder specimen after routine cholecystectomy has also been challenged by various investigators stating that macroscopic features are always present in cases of GB carcinoma which can be used to selectively send specimens for histopathology. $9,10,11$ Our aim is to study the frequency of incidental carcinoma of gall 
bladder in patients undergoing routine cholecystectomy and to study the demographic profile and prognosis of these patients.

METHODS: A retrospective study was done on all routine laparoscopic cholecystectomy cases ( $\mathrm{n}=371$ ) performed from Jan 2010 to Sep 2012 at KIMS Hospital and Research Center, Bangalore. The surgical case notes including the preoperative entry, the operating notes and all clinical information and the histopathological reports of the patients and their follow up were evaluated. The incidence and clinico- pathogical factors (presenting symptoms, demographics, histopathology, staging and follow up) of gallbladder carcinoma that were detected incidentally during routine cholecystectomy were reviewed and analysed. The results were tabulated and a through review of literature was done. All the cases in which cholecystectomy was done but had any suspicion of malignancy during preoperative evaluation was excluded from the study. The study was ethically approved by the ethical committee of our hospital.

RESULTS: A total of 371 cholecystectomies were performed during the study period. Female patients constituted $57 \%$ of the study group. The fifth decade $(26.14 \%)$ and the sixth decade $(25.06 \%)$ was the most affected age group. Charts 1 and 2 describe the presenting symptoms and the clinical signs.

DISCUSSION: Etiological factors for gall bladder ca are gallstones, porcelain gallbladder, adenomatous polyps of the gallbladder, chronic infection with Salmonella typhi, carcinogen exposure (e.g., miners exposed to radon), and abnormal pancreaticobiliary duct junction (APBDJ). ${ }^{5}$ Most of the cases of carcinoma GB are diagnosed at advanced stage and have a poor prognosis having 5 year survival rate of $<5 \%$. When detected at early stages prognosis may improve significantly up to $90-100 \%$ five years survival rate. ${ }^{12,13}$ However these carcinomas are known to have delayed onset of symptoms. They are also usually diagnosed as incidental finding post cholecystectomy and theoretically this group carries the best prognosis. ${ }^{14}$ In our series the incidence rate of incidental GB carcinoma in routine post-cholecystectomy cases was $2.15 \%$. Amanullah et al (1.8\%) and Shrestha $\mathrm{R}$ et al (1.4\%) have incidence less than ours whereas Zhang WJ et al has shown its occurrence as low as $0.19 \%$ and Navqi et al has found its occurrence as high as 5.9\%. ${ }^{15-18}$ Most of the patient with incidental carcinoma GB were Females constituted three fourths of the incidental ca patients. (M:F ratio 1:3). Fifth decade was the most common age group involved (26.1\%). It is a standard practice to perform routine histopathological examinations for all cholecystectomy specimens. Various studies including the working report of Royal College of Pathologists have recommended for this routine standard practice. ${ }^{15,19}$ Recently few other investigators have challenged this practice. They have suggested that all cases of GB carcinoma have some macroscopic features like thickened fibrotic wall, mucosal ulceration, nodular mucosa or polyploidy projections which can be used as a guide for sending for histopathology. Limitations of the study are its retrospective nature.

CONCLUSION: The rate of incidental carcinoma of gall bladder in our setting was found to be $2.15 \%$. Our study strongly recommends routine histopathological examination in all cholecystectomy specimens as they help in detection of majority of cases of occult carcinoma GB. 
This study also highlights that although primary carcinoma of gall bladder are known for their late presentation and hence poor survival rates; occult carcinoma GB diagnosed incidentally on histopathological examination of post-cholecystectomy specimen are usually detected at earlier stages and thus have better prognosis.

\section{REFERENCES:}

1. Murshid KR. Asymptomatic gallstones: Should we operate? Saudi J Gastroenterol 2007; 13: 57-69.

2. Jemal A, Siegel R, Ward E, Murray T, Smigal C, Thun MJ. Cancer statistics, 2006. CA Cancer J Clin 2006; 56:106-130.

3. Muratore A, Polastri R, Caussotti L. Radical surgery for gallbladder cancer: current options. Eur J Sur Oncol 2000; 5: 438-43.

4. Oddsdottir M, Hunter JG. Gall bladder and the extrahepatic biliary system. In: Brunicardi FC, Andersen DK, Billiar TR, Dunn DL, Hunter JG, Pollock RE, editors. Schwartz's principle of surgery (8th ed.). New York: McGraw Hill; 2005.1187-1219.

5. Whang EE, Zinner MJ. Cancer of the Gall bladder and the bile ducts. In: Zinner MJ, Ashley SW, editors. Maingot's abdominal operations (11th ed.). New York: McGraw Hill; 2007. 92135.

6. Have PC, Simpson KJ, Garden OG. Liver and biliary tract disease. Hasle; C, Chilvers ER, Boon NA, College NR (19th ed.). Churchill Livingstone. 831-88.

7. James MC. Liver and biliary tract. In: Kumar V, Abul KA, Nelson F, editors. Robins and Cotran Pathologic basis of Disease (7th ed.). Philadelphia: Elsevier; 2004. 935.

8. Russel RCG. The gall bladder and bile ducts. In: Russel R.C.G, Williams N.S, Bulstrode C.J.K, editors. Bailey and Love, Short practice of Surgery (24th ed.).London: Hodder Arnold Publication; 2004.1095-1113.

9. Mittal R, Jesudason MR, Nayak S. Selective histopathology in cholecystectomy for gallstone disease. Indian J Gastroenterol 2010; 29: 26-30.

10. Darmas B, Mahmud S, Abbas S, Baker AL. Is there any justification for the routine histological examination of straightforward cholecystectomy specimens? Ann Roy Coll Surg Engl 2007; 89: 238-41.

11. Bazoua G, Hamza N, Lazim T. Do we need histology for a normal-looking gallbladder? Surgeon 2003; 1: 233-5.

12. Eric CH, Lau WY. Gallbladder cancer, a comprehensive review. The Surgeon 2008; 10-19.

13. Misra MC, Guleria S. Management of cancer gallbladder found as a surprise on a resected gallbladder specimen. J Surg Oncol 2006; 93:690-8.

14. Contini S, Dalla Valle R, Zinicola R. Unexpected gallbladder cancer after laparoscopic cholecystectomy. Surg Endosc 1999; 13:264-7.

15. Amanullah MK, Rizwn AK, Shahid S, Veena M. Occult carcinoma of gallbladder: Incidence and role of simple cholecystectomy. JK- Practitioner 2007; 14: 22-3.

16. Sherestha R, Tiwari M, Ranabhat SK, Aryal G, Rauniyar SK, Shrestha HG. Incidental gallbladder carcinoma: value of routine histological examination of cholecystectomy specimens. Nepal Med Coll J 2010; 12(2): 90-4. 
17. Zhang WJ, Xu GF, Zou XP et al. Incidental Gallbladder Carcinoma Diagnosed During or After Laparoscopic Cholecystectomy. World J Surg 2009; 33:2651-6.

18. Naqvi SQH, Mangi IH, Dahri FJ, Khaskheli QA, Akhund AA. Frequency of carcinoma of gall bladder in patients with cholelithiasis. Gomal Journal of Medical Sciences 2005; 3(2): 41-3.

19. Royal College of Pathologists. Histopathology and cytopathology of limited or no clinical value. Report of working group of The Royal College of Pathologists, 2nd edition London: Royal College of Pathologists, 2005

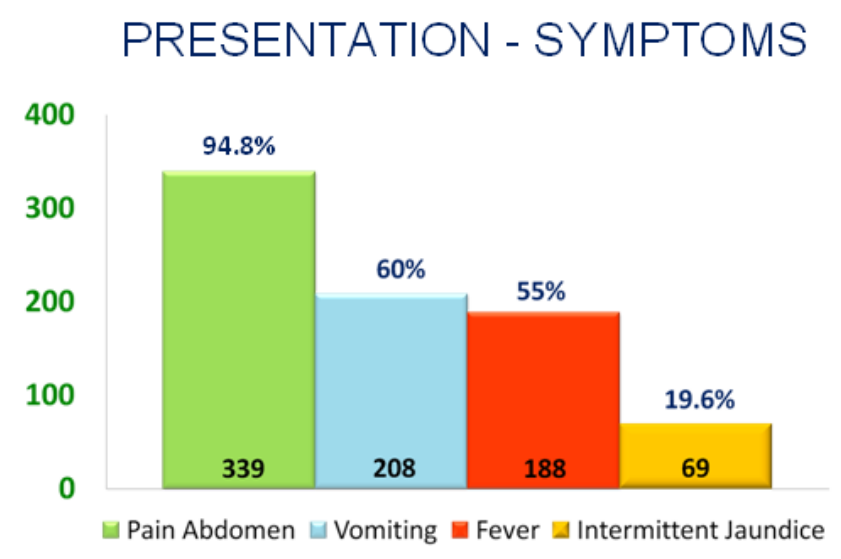

\section{CHART 1}

\section{PRESENTATION - SIGNS}

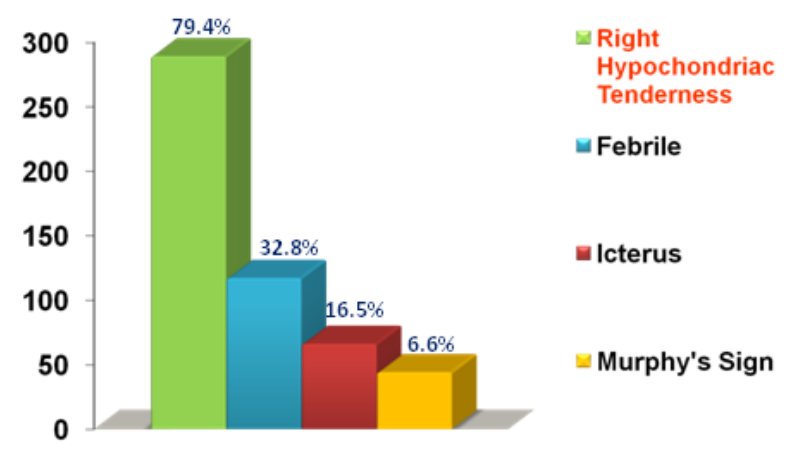

\section{CHART 2}

Ultrasonography showed calculus in $77 \%$ of patients and wall thickness was more than $4 \mathrm{~mm}$ in 34 patients. Histopathological analysis of the specimens revealed chronic calculous cholecystitis as the most common pathology, followed by acute and acute on chronic cholecystitis. Eight patients $(2.15 \%)$ showed evidence of malignancy with $75 \%$ of the patients being females. (Chart 3 ) 


\section{ORIGINAL ARTICLE}

\section{HISTOPATHOLOGICAL REPORT}

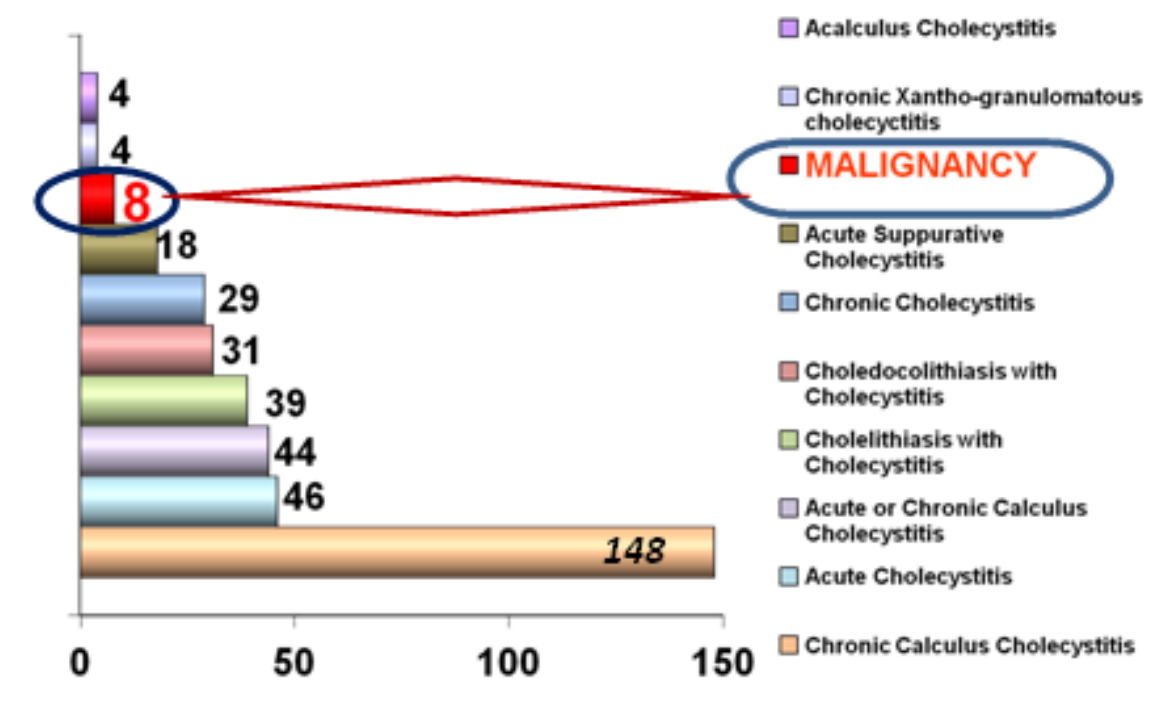

CHART 3

Three of these specimens had pathological staging as pT1 and 5 had pT2 stage. Two of patients in pT1 stage had well differentiated adenocarcinoma and one had moderately differentiated adenocarcinoma. However patients with pT2 staging had varied histology as shown in table 1.

\begin{tabular}{|c|c|c|c|c|c|}
\hline & GROSS FEATURES & $\begin{array}{c}\text { CUT } \\
\text { SECTION }\end{array}$ & $\begin{array}{c}\text { WALL } \\
\text { THICKNESS }\end{array}$ & HPE & STAGE \\
\hline $\begin{array}{c}\text { CASE } \\
1\end{array}$ & NODULAR MUCOSA & GREY WHITE & $4 \mathrm{~mm}$ & MDA & pT2 \\
\hline $\begin{array}{c}\text { CASE } \\
2\end{array}$ & $\begin{array}{l}\text { DISRUPTED } \\
\text { MUCOSAL } \\
\text { AR CHITECTURE }\end{array}$ & GREY WHITE & $3.2 \mathrm{~mm}$ & WDA & pT2 \\
\hline $\begin{array}{c}\text { CASE } \\
3\end{array}$ & $\begin{array}{l}\text { IRREG ULAR MU COSA } \\
\text { NO CALCULI }\end{array}$ & $\begin{array}{c}\text { GREY WHITE \& } \\
\text { HEMORR HAGI } \\
\text { C }\end{array}$ & $5 \mathrm{~mm}$ & WDA & pT1b \\
\hline $\begin{array}{c}\text { CASE } \\
4\end{array}$ & THICKENED WALL & GREY WHITE & $5 \mathrm{~mm}$ & $\begin{array}{l}\text { INFILTRATIN } \\
\text { G WDA }\end{array}$ & pT2 \\
\hline $\begin{array}{c}\text { CASE } \\
5\end{array}$ & IRREG ULAR MUCOSA & GREY WHITE & $5 \mathrm{~mm}$ & WDA & pT1a \\
\hline $\begin{array}{c}\text { CASE } \\
6\end{array}$ & $\begin{array}{l}\text { CAULIF LOWER } \\
\text { GROWTH }\end{array}$ & GREY WHITE & $4 \mathrm{~mm}$ & SQ CELL CA & pT2 \\
\hline $\begin{array}{c}\text { CASE } \\
7\end{array}$ & IRREG ULAR MUCOSA & GREY WHITE & $5 \mathrm{~mm}$ & $\begin{array}{l}\text { INFILTRATIN } \\
\text { G WDA }\end{array}$ & pT2 \\
\hline $\begin{array}{c}\text { CASE } \\
8\end{array}$ & THICKENED WALL & $\begin{array}{c}\text { GREY WHITE \& } \\
\text { HEMORRHAGI } \\
\text { C }\end{array}$ & $5 \mathrm{~mm}$ & MDA & pT1b \\
\hline
\end{tabular}

TABLE 1 


\section{ORIGINAL ARTICLE}

\section{TREATMENT(T2 LESION)}

\begin{tabular}{|c|c|c|c|c|c|c|}
\hline $\begin{array}{l}\mathrm{AG} \\
\mathrm{V} / \mathrm{E}\end{array}$ & S\&S & $\begin{array}{c}\text { PRE OP } \\
\text { DIAGNOSIS }\end{array}$ & Sx & HPE & $\mathrm{Rx}$ & F儿 \\
\hline $70 / \mathrm{m}$ & $\begin{array}{l}\text { RT HYPO } \\
\text { PAIN }\end{array}$ & CHOLELITHIASIS & $\begin{array}{l}\text { LAP } \\
\text { CHOLE }\end{array}$ & MDA & CT & $\begin{array}{l}25 \text { MO } \\
\text { \&ALIVE }\end{array}$ \\
\hline $70 / \mathrm{m}$ & $\begin{array}{l}\text { PAIN ABD \& } \\
\text { INT } \\
\text { JAUNDICE }\end{array}$ & $\begin{array}{c}\text { A/C CAL CHOLECYSTITIS } \\
\text { \& EMPYEMA }\end{array}$ & $\begin{array}{l}\text { LAP } \\
\text { CHOLE }\end{array}$ & WDA & $\begin{array}{l}\text { WHIPP } \\
\text { LES }\end{array}$ & $\begin{array}{l}24 \mathrm{MO} \\
\text { \&ALIVE }\end{array}$ \\
\hline $78 \AA$ & $\begin{array}{l}\text { RT HYPO } \\
\text { PAIN \& } \\
\text { FEVER }\end{array}$ & $\begin{array}{l}\text { CAL CULOUS } \\
\text { CHOLECYSTITIS }\end{array}$ & $\begin{array}{l}\text { LAP } \\
\text { CHOLE }\end{array}$ & $\begin{array}{l}\text { INF. } \\
\text { WDA }\end{array}$ & CT & $18 \mathrm{Mo}$ \\
\hline $65 \pi$ & $\begin{array}{l}\text { RT HYPO } \\
\text { PAIN }\end{array}$ & CHOLELITHIASIS & $\begin{array}{c}\text { LAP } \\
\text { CHOLE }\end{array}$ & $\operatorname{scc}$ & CT & $\begin{array}{l}12 \mathrm{MO} \\
\& \text { ALIVE }\end{array}$ \\
\hline $50 \pi$ & $\begin{array}{l}\text { INT } \\
\text { JAUNDICE }\end{array}$ & $\begin{array}{c}\text { CHRONIC } \\
\text { CHOLESYSTITIS }\end{array}$ & $\begin{array}{l}\text { LAP } \\
\text { CHOLE }\end{array}$ & $\begin{array}{l}\text { INF. } \\
\text { WDA }\end{array}$ & CT & $\begin{array}{l}12 \mathrm{MO} \\
\text { \&ALIVE }\end{array}$ \\
\hline
\end{tabular}

\section{TABLE 2}

All patients in our study except one were treated with chemotherapy with Folfox regimen. Their respective follow-up periods are mentioned in the table 2. Our protocol is as follows: (Figure)

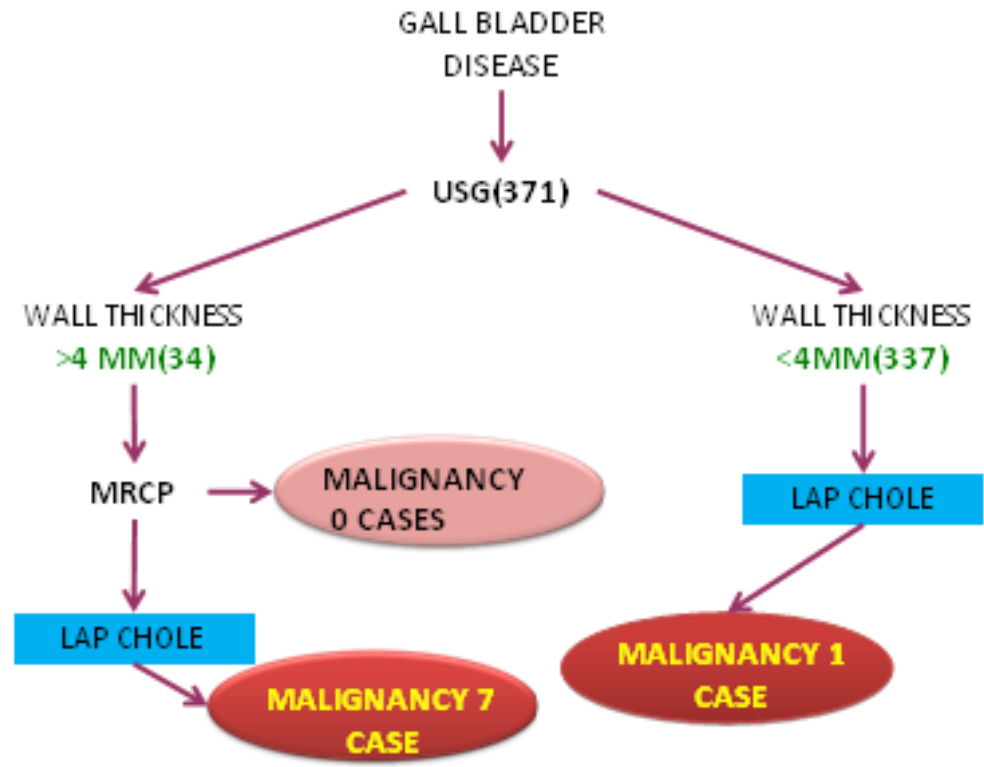

\section{FIGURE 1}

Only one patient in the pT2 category underwent sphincter Sparing Whipple's pancreaticoduodenectomy. CA 19-9 and CEA were used as markers for follow-up study and recurrence detection. 